\title{
Higher Education in South Africa at the Crossroads
}

\author{
Prof. K.C. Moloi \\ Vaal University of Technology, Faculty of Human Sciences \\ Vanderbijlpark, South Africa, 1900 \\ conniem@vut.ac.za \\ Ms. T.S. Mkwanazi \\ thabilem@yahoo.com \\ Mr. T.P. Bojabotseha \\ tebohog@vut.ac.za
}

\section{Doi:10.5901/mjss.2014.v5n2p469}

\begin{abstract}
In this article the authors explore the current state of higher education in South Africa in an attempt to locate the study within the current socio-economic and political imperatives driven by the knowledge economy and a changing global environment. The article is based largely on an examination of current education policy documents that address future developments in higher education in the South African context. The key aim is to understand the trajectory that higher education in South Africa is taking to help millions of young people in South Africa (including those who are currently excluded from sought-after fields of study and training institutions) access those opportunities that are available and, in the process, to promote equity and redress, quality, development, democratisation, academic freedom, institutional autonomy, effectiveness and efficiency, and public accountability. The authors acknowledge that great strides have been taken in the country to make higher education a reality for many young people.
\end{abstract}

Keywords: Curriculum restructuring, post-school education, socio-economic development, flexible curriculum structure

\section{Introduction}

Much has been achieved in South African higher education in terms of addressing the imbalances inherited from the past Apartheid regime (segregationist government). These imbalances included race, gender, social and educational inequalities which have resulted in the complex, intractable challenges that the country faces. Given the new and daunting demands for competitiveness fuelled by globalisation, internationalisation and technological advancements, as well as the need to attend to the local socio-economic, cultural and intellectual life of a rapidly changing society (Badat 2010: 5), new challenges are emerging for higher education in South Africa. These challenges include, amongst others, structural problems in terms of the under-preparedness of students entering university for a particular educational level, that is, discontinuity in terms of the knowledge gap between secondary and higher education, and between higher education and the labour market (Nzimande 2012: xii). Furthermore, the Council on Higher Education (CHE) (2013) indicates that 892936 students (726 882 undergraduates and 138610 postgraduates) were enrolled in South Africa's public higher education institutions in 2010 (South Africa Info Brand 2013: 1). However, graduate output has been found to have major shortcomings in terms of overall numbers, equity and the proportion of the student body that succeeds. The CHE (2013: 19) indicates that, for example, only about one in four students in contact institutions graduate in regulation time (for example, for a three-year degree). Only $35 \%$ of the total intake and $48 \%$ of contact students graduate within five years. When allowance is made for students taking longer than five years to graduate, or returning to the system after dropping out, it is estimated that $55 \%$ of the intake will never graduate (CHE 2013: 15).

Access, redress and social equity are essential in view of the extreme racialisation and gendering of higher education that occurred under colonialism and apartheid, which bequeathed South Africa a predominantly white and male academic work force (Barnett 2000), and which still persist, with white completion rates being on average 50\% higher than African rates (CHE 2013: 15). Cloete and Butler-Adam (2012: 1) indicate in a report entitled Responding to 
the Education Needs of Post-School Youth that youth are currently stigmatised as being 'not in education, employment or training (NEETs)'. In accordance with new constitutional and social imperatives and higher education goals and policies, post-1994 South African universities have needed to confront these challenges (Alexander 2007).

There are demands to advance access to quality higher education, through equity and redress, quality, development, democratisation, academic freedom, institutional autonomy, effectiveness and efficiency, and public accountability (Badat 2010: 7). Added to these demands is the need to produce and retain a new generation of academics with the requisite pedagogical content knowledge, disciplinary knowledge, requisite skills and competencies so that they can contribute to the country's political and knowledge economy and to changes in the future (Nzimande 2012: viii). However, a preoccupation with simply reproducing a new generation of academics without any purposeful attention to access, redress and social equity is likely largely to reproduce the inequities that characterised apartheid higher education. The overall challenge, therefore, is to produce and retain a new generation of academics and simultaneously transform the historical social composition of the academic work force in higher education (Badat 2010: ). Because the substantive transformation and development of South Africa's universities and the enhancement of their academic capabilities are key national goals, the challenge is to produce and retain a new generation of academics, with profound implications for the character of this new generation (CHE 2013: 18). The upshot is that a new generation of academics must not only be increasingly made up of blacks and women South Africans, but must also possess the intellectual and academic capabilities related to teaching and learning, research and community engagement that are a necessary condition for transforming and developing South Africa's universities and enhancing their academic capacities (Barnett 2008).

In light of the above, the purpose of this paper is to gain an understanding of the challenges faced by South African higher education in the midst of the complex contradictory and countervailing forces of a developing society within a rapidly changing and competitive global context.

\section{Problem Statement}

Given that in 2008 there were 874680 students at South African higher education institutions, 799490 at public institutions and 75190 at private institutions, what strategies are required from institutions of higher education to ensure that most of these students graduate in regulation time? A study conducted by Cloete (2009) shows that there were 640 166 students at further education and training colleges, 520235 at public institutions and 147901 at private institutions simultaneously and that 2781185 people between the ages of 18 and 24 were neither in employment, nor studying at education or training institutions in 2008. Presently, South Africa has a pressing need for more graduates of good quality to advance all forms of social and economic development. These graduates should be able to build up education by providing a strong new generation of teachers, college lecturers, academics and educational leaders (CHE 2013). Cloete (2009: 43) has noted that the fact that $41.6 \%$ of young people aged 18 to 24 years are neither employed nor engaged in education or training is not only an educational problem, but constitutes a social and economic disaster.

Such a situation lends itself to the development of a peculiar identity within a specific social and historical context. In this regard, Castells (2000: 6) argued that identity, as with everything in this world, is not made out of words or feelings or moods, it is made material, as everything else is, with the works of history and experience. Alexander, Dawson and Ichharam (2006: 246) observe that the manner in which identities are constructed within a given a social context is by the interaction of individuals, where experiences are shared and meaning is attached to those experiences. Thus, there are legitimate concerns that post-1994 higher education should not reproduce the imbalances of the past. In relation to this, Nzimande (2012: viii) has warned that the barriers to post-school education today are not formalised or legalised through the colour of one's skin or racial designation. However, the legacy of apartheid lives on in the host of problems related to the poor quality of education in many parts of the country, and the socio-economic conditions that young people have to grapple with as they pursue their careers.

\section{Context of Higher Education in South Africa}

Many of South Africa's universities are world-class academic institutions, at the cutting edge of research in certain spheres. Although subsidised by the state, the universities are autonomous, reporting to their own councils rather than government (SouthAfrica.info 2013: 1). There are two elements in the creation of a new differentiated institutional landscape in South African higher education. One is institutional restructuring, which has reduced the precious 36 higher education institutions to 23 through mergers and incorporations based on various criteria. The result is the present 
landscape of 11 universities, six comprehensive universities (one distance) and six universities of technology. Two institutes of higher education were created, as facilities through which particular academic programmes of the existing universities could be provided in provinces that did not have universities. The other element is the negotiation of the academic offerings of institutions, in terms of which institutions are restricted to specific approved undergraduate and postgraduate qualifications and programmes, must seek state approval for the offering of new qualifications, and must receive quality accreditation from the $\mathrm{CHE}$ (Badat 2009).

The institutional restructuring that occurred after 2001 provided the opportunity to reconfigure the higher education system so that it was more suited to the needs of a developing democracy. While various challenges remain, the foundations have been laid for a new higher education landscape. Nonetheless, differentiation has been and remains a difficult, contentious and challenging policy issue for a number of reasons (Badat 2009). If there is an in-principle opposition to differentiation and diversity and a South African higher education institutional landscape comprised of differentiated and diverse universities, this would run counter to the thrust of post-1994 higher education policy and will require major policy engagement and negotiations with government on the part of Higher Education South Africa.

The National Plan for Higher Education (2001) set the target of a 20\% participation rate by 2011/2016. The participation rate was $15 \%$ in 2001 and increased by only $1 \%$ by 2008 , which has negative consequences for economic and social development. The Department of Higher Education and Training (DHET) is seeking to incorporate an additional 100000 students within higher education, in a context in which the capacities of public universities are already stretched. Concomitantly, there is a pressing need for enhancing pass rates and graduation rates and also for enhancing the quality of the graduates of many institutions. In 2010, the public higher education institutions produced 153741 qualifications at all levels, with 74612 qualifications in the human and social sciences, 41724 in business and commerce and 37405 qualifications in science and technology (SouthAfrica.info 2013: 1). Higher education is also offered at private institutions, of which there are 88 registered and 27 provisionally registered with the Department of Higher Education to confer specific degrees and diplomas. Since 2009, the Department of Higher Education and Training has also been responsible for Further Education and Training (FET), which covers training provided from Grades 10 to 12, including career-oriented education and training offered in technical colleges, community colleges and private colleges. There are currently around 450 registered FET colleges in South Africa. The National Student Financial Aid Scheme (NSFAS) was established in 1999 to make higher education possible for financially disadvantaged students through loans and concessions, such as not charging interest on student loans until 12 months after a student has graduated.

A Task Team on Undergraduate Curriculum Structure has been commissioned by the CHE to investigate undergraduate curriculum reform in South Africa for a flexible curriculum structure. This task team has identified three major problems with the existing curricula proffered in institutions of higher education. As has been stated above, the first of these is the major structural problem of discontinuity between secondary and higher education in South Africa. The second major structural problem is that, as recent in-depth curriculum analysis has increased, many curricula contain key transitions for which many students are differentially prepared. These transitions can be between knowledge domains and various forms of intellectual demand. The third major structural problem is the need for undergraduate curricula to be enhanced in order to meet contemporary local and global conditions. The issues discussed here indicate that higher education in South Africa is at the crossroads.

\section{Literature Review}

There has been an intractable tension between a number of values and goals of higher education. For example, to the extent that government and universities have sought to pursue social equity and redress and quality in higher education simultaneously, difficult political and social dilemmas, choices and decisions have arisen, especially in the context of inadequate public finances and academic development initiatives to support under-prepared students, who tend to be largely black and/or of working class or rural poor social origins. South Africa's student participation rate - that is, the proportion of 18- to 24 -year-olds in higher education - is a low $16 \%$. Equity has yet to be achieved: almost $58.5 \%$ of whites and around $51 \%$ of Indians enter higher education. The rate for coloureds is $14.3 \%$, while that for blacks is even lower at $12 \%$. The reason for this is generally understood to be poor quality primary and secondary schooling, which is a priority for the current government. The greatest challenges for schooling lie in the poorer, rural provinces such as the Eastern Cape and KwaZulu-Natal. Schools are generally better resourced in the more affluent provinces such as Gauteng and the Western Cape.

It should be accepted that, for good political and social reasons, values, goals and strategies that are in tension need to be pursued simultaneously. Paradoxes have to be creatively addressed and policies and strategies have to be 
devised that can satisfy multiple imperatives, balance competing goals and enable the pursuit of equally desirable goals. To the extent that certain conditions, including inadequate financial resources, make trade-offs necessary and result in particular choices and decisions at DHET and institutional levels, there should be open acknowledgement of the basis of such choices and decisions, and communication between various constituencies in this regard. There is a critical and immediate need to reconceptualise and clarify the scope, structure and landscape of the post-school system and institutions as well as to expand opportunities for high-quality post-school education and training (CHE 2013). Such a process should also clarify the purposes and roles of higher education institutions as opposed to further education and training colleges and other possible post-school institutions, and address the need for an expansion of higher education opportunities in order to realise the goal of a $20 \%$ participation rate in higher education. The reconceptualisation of the scope, structure and landscape of post-school institutions will almost certainly require legislative and policy changes, the possible redirection of available funds (the National Skills Levy funds) and the investment of new funds (CHE 2013).

\section{Teaching and Learning, Research and Community Engagement}

With respect to teaching and learning, research and community engagement, in a number of areas of learning and teaching, institutions offer academic programmes that produce high-quality graduates with the knowledge, competencies and skills to practise occupations and professions locally and anywhere in the world. Various areas of research are characterised by excellence and the generation of high-quality fundamental and applied knowledge for scientific publishing in local and international publications, for economic and social development and innovation, and for public policy. In a variety of areas, there are also important and innovative community engagement initiatives that link academics and students and communities. There has been an increased and broadened participation in higher education to advance social equity and meet economic and social development needs, a crucial goal, given the legacy of disadvantage of black and women South Africans, especially those of working class and rural poor origins (Badat 2010: 7).

Apart from retirees needing to be replaced, it is also necessary to take into account the additional academics that will be required if the university system expands, as envisaged by the CHE proposal for undergraduate curriculum reform in South Africa (2013). The current outputs of masters and doctoral graduates also constrain the transformation of the social composition of the new generation of academics (Scott, 2007:10). Because the qualifications and expertise of academics make them relatively mobile, a certain proportion will inevitably be lost to the public and private sectors, and to emigration (CHE, 2008:8). As part of the vision of a transformed democratic, non-racial and non-sexist system of higher education (DoE 1997: 1.14), higher education was called upon to advance specific goals including the improvement of the quality of teaching and learning throughout the system and, in particular, to ensure that curricula are responsive to national, and regional context and to promote quality and quality assurance through the accreditation of programmes, programme evaluations and institutional audits (Badat 2010: 7). The legislation related to employment equity in South Africa was recently amended to define only black and women South Africans as 'designated groups' that may be the beneficiaries of employment equity (Scott, 2007:10).

\section{Intellectual Spaces}

To undertake its diverse educational and social purposes effectively, a university must have a commitment 'to the spirit of truth' (Graham, 2005:163), and must possess academic freedom and institutional autonomy. However, while academic freedom and institutional autonomy are necessary conditions, they are also rights in which duties inhere (Jonathan, 2006). In the South African context, we must recognise, as André du Toit urges, 'the legacies of intellectual colonisation and racialisation as threats to academic freedom' (2000); and that 'the powers conferred by academic freedom go hand in hand with substantive duties to deracialise and decolonise intellectual spaces' (Bentley et al, 2006). Higher education holds the promise of contributing to social justice, development and democratic citizenship. Yet this promise often remains unrealised and, instead, universities frequently continue to be a powerful mechanism of social exclusion and injustice, through both their own internal thinking, structures, cultures and practices and their external conditioning by the wider society.

Any serious agenda of inclusion in higher education entails the duty of using 'the powers conferred by academic freedom' to substantively decolonise, deracialise, demasculinise and degender our inherited 'intellectual spaces'. It means creating the space for the flowering of epistemologies, ontologies, methodologies, issues and questions other than those that have dominated, perhaps even suffocated, intellectual and scholarly thought and writing. This regime of 
social exclusion extends well beyond issues of access and admissions to universities. It includes the question of the opportunities for intellectual, social and citizenship development and for success. It extends to the issues of institutional and academic cultures, and largely ignored epistemological and ontological issues associated with learning and teaching, curriculum development and pedagogical practice. It further extends to the very ideas and conceptions of the purposes and roles of universities.

\section{Funding}

Education in South Africa, in comparison with most other countries, gets a very large slice of the public pie - around 20\% of total state expenditure. It receives the largest share of government spending. More money is always needed to address the huge backlogs left by 40 years of apartheid education. Under that system, white South African children received quality schooling virtually for free, while their black counterparts had only 'Bantu education', a keystone of the overall apartheid system. Although today's government is working to rectify the imbalances in education, the apartheid legacy remains. Illiteracy rates currently stand at around 18\% of adults over 15 years old (about 9 million adults are not functionally literate), and teachers in township schools are poorly trained. Despite the challenges, much has been achieved since apartheid legislation was scrapped. For example, in 1993 nearly half of all students in higher education institutions were white, but since 1994, black African enrolments have nearly doubled, growing by $91 \%$ (or 4.4\% a year), while overall enrolments have grown by $41 \%$ (or $2.3 \%$ a year).

However, with the recent DoE allocations to universities of R2.0 billion (2008-2010) and R3.1 billion (2011-2013) for capital infrastructure and 'efficiency' interventions, it is evident that differentiation need not be a zero-sum game. New funds can help make possible the implementation of a policy of differentiation and diversity, in which universities, through negotiation with the DoE, pursue specific institutional missions and related qualifications and programmes and institutional development trajectories (related to their values, shape and size, infrastructure development needs, strengths and shortcomings), without any necessary financial disadvantaging of historically black institutions (MoE 2001: 16). Of course, it could be argued by historically black universities (and others that perceive themselves to be disadvantaged in one way or another) that there is no fundamental objection on their part to differentiation, but simply that, until the needs (identified and quantified in terms of their negotiated missions and qualifications and programmes) of historically black universities and those that view themselves as disadvantaged are met, any and all new funds for higher education should be allocated to these institutions (MoE 2001: 16).

\section{Differentiation and Diversity}

The history of higher education should not, however, obscure the immense contribution that a differentiated and diverse higher education system can make to the new socio-economic and educational goals and objectives of democratic South Africa. The economic and social needs of South Africa are highly varied and diverse, and a responsive higher education system requires a diverse spectrum of institutions. There is no virtue in homogeneity where every higher education institution seeks to be the same and do the same thing, and all aspire to be a 'research' university (Badat 2010: 14). The creation of a new institutional landscape has, therefore, needed to proceed at two levels simultaneously. On the one hand, it has required the creation of new institutional identities through the development of new institutional missions, social and educational roles, academic qualification and programme mixes, and organisational forms, structures and practices as appropriate for different institutions (Badat 2010.14). On the other hand, the complexity of the restructuring could not end simply with new identities for institutions. It has also needed to confront the historical burden of South African higher education: namely apartheid institutionalised inequities which translated into a 'system' of institutions characterised by educational, financial, material and geographical advantage and disadvantage (Badat 2010: 14).

It may be true that on the part of historically black universities there is no basic opposition to differentiation, but only legitimate concerns about the implications of its implementation in the absence of clear policy signals regarding developmental trajectories, compounded by the absence of significant new funds for higher education. In this case, the issue is not about differentiation as much as it is about: (a) institutional redress, or (b) the balance between financial support for institutional development trajectories of historically black universities and those that view themselves as disadvantaged, and support also for developmental trajectories for historically white universities, to the extent that these universities require support if they are to contribute optimally, in a differentiated and diverse higher education system, to social equity and redress and the economic and social development needs of South Africa and the continent (MoE, 2001: 16). 
The creation of a differentiated and diverse institutional landscape is unlikely to succeed unless all these issues are effectively addressed. It remains to be seen whether the state will pursue differentiation and diversity explicitly and openly on a planned systemic level or opt to do so at the level of individual institutions, using the levers of planning and funding and quality assurance. The institutional restructuring of higher education and a new landscape was intended to 'lay the foundation for an equitable, sustainable and productive higher education system that will be of high quality and contribute effectively and efficiently to the human resource, skills, knowledge and research needs of South Africa' (MoE 2001: 16).

\section{Creating a New Generation of Academics}

In South Africa, racism and patriarchy were key features of colonialism and apartheid and shaped all areas of social life, including higher education. In the specific domain of the academic workforce, the consequence was a racialisation and gendering which bequeathed to South Africa a predominantly white and male academic work force. (CHE, 2008:8). Post1994, in accordance with new constitutional and social imperatives and higher education goals and policies, South African universities have needed to advance redress and social equity for black and women South Africans. At the same time, as the result of the interplay of various factors, it has become clear that South African universities also need to give serious attention to producing and retaining a new generation of academics. It is necessary to emphasise the simultaneity of these two tasks (DoE, 2006). However, the challenge is that South African academics are inadequately remunerated relative to occupations in the public (state, public enterprises and science councils) sector and private sector that require similar levels of qualifications and expertise (CHE, 2008:8). The remuneration differentials between universities and the public and private sectors are significant and have been widening. Consequently, the public and private sectors wield a powerful pull on current academics and on masters and doctoral graduates. It also means that there is a minimal flow of potential academics from the private and public sectors to universities, to the detriment of universities, the economy and society (CHE, 2008:8). Furthermore, from the perspectives of social equity and the transformation of universities, universities are also denied the contributions of first-generation black graduates from working class and rural poor origins, given the opportunity costs (lower incomes and support of families) that have to be borne by these graduates. (CHE, 2008:8).

Scott (2007:10) has argued that a preoccupation with simply reproducing a new generation of academics without any concomitant and purposeful attention to redress and social equity for black and women South Africans is likely largely to reproduce the inequalities that characterised apartheid higher education. The overall task, therefore, is to produce and retain a new generation of academics while simultaneously transforming the historical social composition of the academic work force. There is, however, an additional important task. If the substantive transformation and development of South Africa's universities and the enhancement of their academic capabilities are indeed key national goals, this necessarily has profound implications for the character of the new generation of academics that has to be produced (DoE, 2006). The corollary is that a new generation of academics must not only be increasingly constituted by blacks and women South Africans, but must also possess the intellectual and academic capabilities related to teaching and learning, research and community engagement that are a necessary condition for transforming and developing South Africa's universities (CHE, 2008:8)

\section{Conclusion}

It is unquestionable that serious involvement is required on the part of the government and universities to improve access, equity and quality for all young people in South Africa. A failure to finance and support a new generation of highquality academics will result in the inability to realise national and educational goals. Redress and social equity and the pace and degree of the deracialisation and degendering of the academic work force is imperative in a changing, intellectually globalised world. The goal of transforming and developing South African universities, including improving their teaching and research capabilities, is also imperative, given global competitiveness and the war for the best brains. This has implications for the ability of universities to contribute to social and economic development and democracy through a new generation of competent academics that are committed to critical and independent scholarship and the advancement of social justice. 


\section{References}

Alexander, N. (2007). Affirmative Action and the Perpetuation of Racial Identities in Post-Apartheid South Africa. Transformation, No. 63:

Alexander, P; Dawson, M.C \& Ichharam, M. (Eds.). (2006). Globalisation and new identities. A view from the middle. Johannesburg: Jacana Media. (Pty) Ltd.

Badat, S. (2010). The challenges of transformation in higher education and training institutions in South Africa. Development Bank of Southern Africa.

Barnett, R. (2000). Realizing the University in an Age of Super complexity. Milton Keynes: Open University Press

Barnett, R. (2008). Engaging the Curriculum: A Missing Debate. Higher Education Close Up 4 Conference, University of Cape Town, 2628 June.

Castells, M. 2000. Globalization, identity and the state. Social Dynamics, 26(1).

Cloete, N. (Ed.). (2009). Responding to the educational needs of post-school youth: Determining the scope of the problem and developing a capacity-model. Cape Town: Centre for Higher Transformation.

Council on Higher Education (CHE). 2013. A proposal for undergraduate curriculum reform in South Africa: the case for a flexible curriculum structure. Report of the Task Team on Undergraduate and Curriculum Structure. Discussion Document. Pretoria: CHE.

Council on Higher Education (2008 forthcoming). Post-Graduate Studies in South Africa: A Statistical Study. Pretoria.

Committee of Heads of Research and Technology (COHORT). (2004). Securing Tomorrow Today: Facing the Challenge of Reproducing and Transforming the Social Composition of New Generations of South African Science and Technology Person power. Draft Policy Report. Pretoria: November.

Department of Education. (1997). Education White Paper 3: A Programme for the Transformation of Higher Education. Pretoria.

Department of Education. (2006). Education Statistics in South Africa at a Glance in 2005. Pretoria.

Herman, C. (2008). Political Transformation and Research Methodology in Doctoral Education. Higher Education Close Up 4 Conference, University of Cape Town, 26-28 June

Kapur, D. and Crowley, M. (2008). Beyond the ABCs: Higher Education and Developing Countries. Working Paper Number 139. Washington DC: Centre for Global Development, February.

Kennedy-Dubourdieu, E. (2006). Race and Inequality: World Perspectives on Affirmative Action. Hampshire: Ash gate.

Ministry of Education. (2001). National Plan for Higher Education. Pretoria.

Moore, J. (2005). Race and College Admissions: A Case for affirmative Action. Jefferson: McFarland \& Company.

Morrow, W (1993). Epistemological Access in the University. AD Issues, Vol. 1, No. 1. Academic Development Programme, University of the Western Cape.

Nzimade, B. 2012. Minister's Preface. Green paper for post-school education and training. Republic of South Africa: Department of Higher Education and Training.

Perold, H; Cloete, N \& Papier, J. 2012. Shaping the Future of South Africa's Youth. Rethinking post school education and skills training. Somerset West: African Minds for the Centre of Higher Education Transformation (CHET), Southern African Labour and Development Research Unit (SALDRU) and the Further Education and Training Institute (FETI).

Republic of South Africa (1996) Constitution of the Republic of South Africa, Act No. 108.

SouthAfrica.info. Brand South Africa country portal. Education in South Africa. [Online] Available: http://www.southafrica.info/about leducation/education.htm\#higher (Accessed: October 23, 2013) 
